\title{
IDENTIFIKASI SAMPAH PESISIR DI DESA RUMAH TIGA KOTA AMBON
}

\author{
(Identification of Coastal Debris at Rumah Tiga Village Ambon City)
}

\author{
N. Chr. Tuhumury ${ }^{1 *}$ dan I. Kaliky ${ }^{2}$ \\ ${ }^{1}$ Jurusan Manajemen Sumberdaya Perairan Fakultas Perikanan dan Ilmu Kelautan Universitas Pattimura \\ ${ }^{2}$ Mahasiswa Program Studi Manajemen Sumberdaya Perairan \\ Fakultas Perikanan dan Ilmu Kelautan Universitas Pattimura \\ *_louhen@yahoo.com
}

\begin{abstract}
ABSTRAK: Sampah pesisir merupakan permasalahan global yang berasal dari aktivitas manusia atau antropogenik. Sampah ini memberikan pengaruh bagi pertumbuhan organisme di perairan dan juga bagi manusia sebagai pengguna sumberdaya pesisir. Tujuan dari penelitian ini yaitu mengidentifikasi serta menganalisis sampah pesisir meliputi jumlah jenis, persentase berat dan kepadatan sampah di Desa Rumah Tiga Kota Ambon. Penelitian dilakukan pada April 2018 di Desa Rumah Tiga, Kecamatan Teluk Ambon. Pengumpulan data sampah dilakukan menggunakan metode Line Transect. Sampah yang dikumpulkan terdiri dari sampah meso dan makro. Sampah makro diperoleh melalui proses penyaringan dengan ayakan ukuran $2,5 \mathrm{~cm}$, sedangkan untuk sampah meso yang tersaring dengan ayakan ukuran $0,5 \mathrm{~cm}$. Jenis sampah yang dikumpulkan kemudian diidentifikasi berdasarkan sistem klasifikasi sampah UNEP (United Nation Environment Programme), selanjutnya dianalisis persentase berat dan kepadatan sampah. Hasil penelitian menunjukkan bahwa pada sampah meso dan makro, klasifikasi sampah pecahan kaca dan keramik memiliki nilai jumlah dan kepadatan yang tertinggi. Presentase berat tertinggi ditunjukkan pada klasifikasi sampah material bangunan berupa bongkahan semen. Selain itu, diperoleh juga sampah logam dan plastik yang walaupun memiliki jumlah yang kecil namun memberikan pengaruh negative terhadap pertumbuhan organisme di perairan.
\end{abstract}

Kata Kunci: Sampah pesisir, kaca dan keramik, logam berat, plastik, Desa Rumah Tiga

ABSTRACT: Coastal debris is a global problem sourced from human or anthropogenic activities. Coastal debris has an influence on the growth of organisms in the waters and also for humans as users of coastal resources. The study was conducted on April 2018 in the Rumah Tiga Village, Teluk Ambon District to identify and to analyze coastal debris which consists of type, relative weight and density of the debris. Sample of debris was collected by using Line Transect method. The debris collected was filtered by using a $2.5 \mathrm{~cm}$ size sieve for macro debris and a $0.5 \mathrm{~cm}$ sieve for meso debris. The filtered debris was then identified based on the debris classification system of UNEP (United Nation Environment Program). The results showed that glass fragments and ceramics had the highest amount and density both in meso and macro debrises while building material in the form of rubble cement had the highest percentage of weight. Metal and plastic debris were also found in small amount, however both debrises are well known have negative influence on the growth of marine organisms.

Keywords: Coastal debris, glass and ceramic, heavy metal, plastic, Rumah Tiga Village 


\section{PENDAHULUAN}

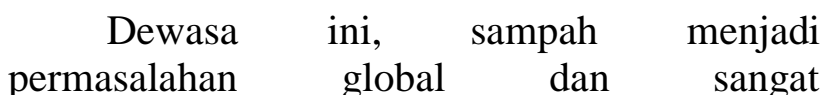
mengkhawatirkan. Sampah merupakan bahan buangan sehari-hari yang dapat dimanfaatkan maupun tidak dapat dimanfaatkan kembali. Sampah yang terdapat di perairan pesisir dan laut berasal buangan hasil aktivitas manusia atau antropogenik. Jenis sampah anorganik seperti plastik memiliki jumlah terbanyak yang ditemukan di perairan tersebut. Berdasarkan data Plastic Europe (2016), konsumsi plastik tahunan global saat ini telah mencapai lebih dari 320 juta ton dengan produksi terbanyak berada pada dekade terakhir ini. Terbukti bahwa sampah plastik yang sulit terurai menjadi faktor tekanan di lingkungan pesisir dan laut dan merupakan ancaman bagi berbagai spesies laut (Poeta, et al., 2017). Volume sampah di kotakota besar dunia diprekiraan akan mencapai 2,2 miliar ton pada tahun 2025 (Rarastri, 2008).

Peningkatan jumlah sampah di perairan pesisir dan laut semakin tinggi sejalan dengan pertambahan penduduk. Jumlah penduduk Kota Ambon dalam kurun waktu lima tahun terakhir meningkat dari 354.464 jiwa di tahun 2012 menjadi 376.152 jiwa di tahun 2017 (BPS, 2018). Tingginya jumlah sampah di perairan pesisir dan laut juga berkaitan erat dengan sikap masyarakat yang telah menjadi kebiasaan yaitu membuang sampah langsung ke pantai atau melalui sungai. Hal ini terbukti dengan banyaknya sampah di perairan Teluk Ambon ketika musim hujan. Masyarakat yang bermukim di pinggiran sungai membuang sampah langsung ke sungai yang mengalir ke laut. Letak pemukiman di pinggiran sungai memudahkan masyarakat melakukan aktivitas tersebut dan telah menjadi kebiasaan negatif. Selain itu, masyarakat sering menganggap bahwa pesisir dan laut merupakan buangan terakhir atau tempat sampah besar yang akan memberikan pengaruh kecil terhadap sumberdaya pesisir dan laut. Sampah yang berada di perairan dapat berupa sampah organik (dapat terurai), sampah anorganik (sulit terurai) dan sampah berbahaya beracun. Sampah organik dapat menimbulkan bau yang menyengat dan mengganggu kesehatan. Sampah anorganik berupa plastik sudah terbukti memiliki peranan dalam menurunkan estetika perairan maupun mengganggu pertumbuhan organisme. Sampah berbahaya beracun berupa logam berat dapat mematikan organisme di perairan.

Desa Rumah Tiga terletak di wilayah pesisir Teluk Ambon dengan berbagai kegiatan masyarakat antara lain aktivitas penambatan perahu, rekreasi pantai, pembangunan pemukiman penduduk di sekitar pantai, pembuangan sampah serta aktivitas pasar tradisional. Berbagai aktivitas yang disebutkan menghasilkan sampah baik organik maupun anorganik di perairan. Hal ini terlihat dengan adanya sampah timbunan sampah khususnya sampah anorganik (plastik) di dekat talud akibat terbawa arus pasang surut. Tujuan dari penelitian ini yaitu mengidentifikasi serta menganalisis sampah pesisir meliputi jumlah jenis, persentase berat dan kepadatan sampah di Desa Rumah Tiga Kota Ambon.

\section{METODE PENELITIAN}

Penelitian dilakukan pada bulan April 2018 di Desa Rumah tiga Kecamatan Teluk Ambon ( Gambar 1). Pengumpulan data sampah dilakukan secara langsung di lapangan dengan menggunakan metode Line Transect. Kriteria segmen pantai untuk sampling sampah pesisir didasarkan pada Pedoman Pemantauan Sampah Pantai (Waluyo, dkk., 2017). Sampah yang dikumpulkan terdiri dari sampah meso dan makro. Sampah makro diperoleh melalui proses penyaringan dengan ayakan ukuran $2,5 \mathrm{~cm}$, sedangkan untuk sampah meso yang tersaring dengan ayakan ukuran $0,5 \mathrm{~cm}$ (Gambar 2). Jenis sampah yang dikumpulkan kemudian diidentifikasi berdasarkan sistem klasifikasi sampah UNEP (United Nation Environment Programme), selanjutnya dianalisis persentase dan kepadatan sampah. 


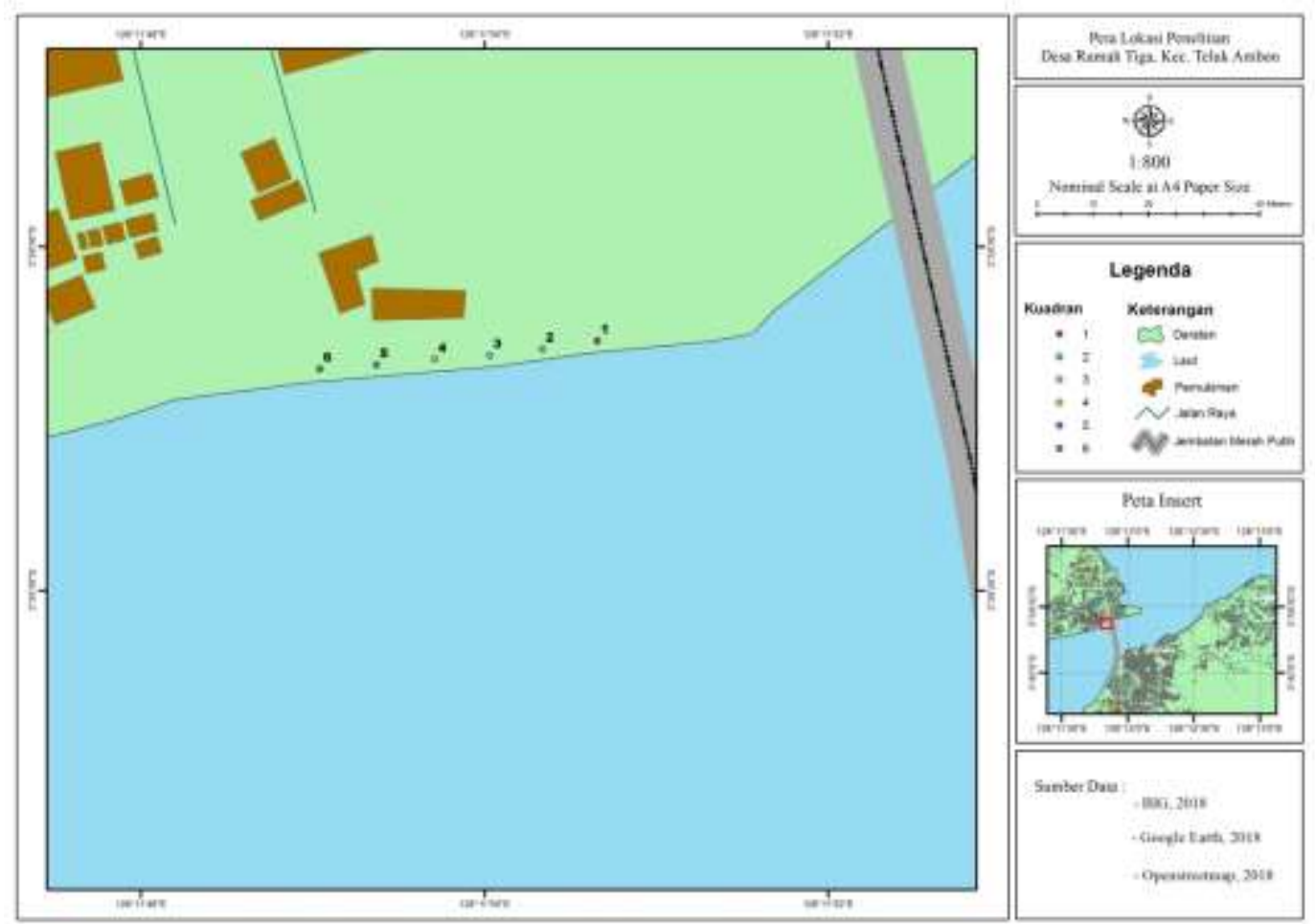

Gambar 1. Lokasi penelitian

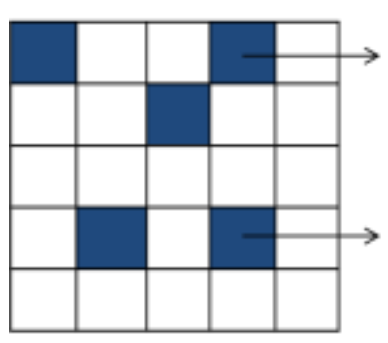

Pengambilan data sampah makro pada petak sampling $1 \times 1 \mathrm{~m}^{2}$

Kuadran $\left(5 \times 5 \mathrm{~m}^{2}\right)$

Petak sampling $\left(1 \times 1 \mathrm{~m}^{2}\right)$

Gambar 2. Kuadran dan petak sampling pengambilan data sampah meso dan makro

\section{HASIL DAN PEMBAHASAN}

Berdasarkan hasil penelitian ditemukan enam klasifikasi sampah meso (Tabel 1) yang tergolong dalam tiga jenis yaitu kaca dan keramik, plastik serta logam. Klasifikasi jenis sampah pecahan kaca dan keramik memiliki jumlah jenis terbanyak yaitu 232 item (Gambar 3). Seperti diketahui, jenis sampah pecahan kaca dan keramik sulit terbawa aurs pasang surut sehingga sampah ini akan menetap dan mengendap lama pada daerah pesisir Desa Rumah Tiga. Letak pemukiman penduduk yang dekat dengan pantai mengakibatkan tingginya jumlah sampah pecahan kaca dan keramik di perairan. Material bangunan merupakan jenis sampah kedua terbanyak yang ditemukan. Jenis sampah ini selain berasal dari aktivitas pembangunan pemukiman masyarakat, juga berasal dari pembangunan jembatan penyeberangan (Jembatan Merah Putih) di Kota Ambon. Pembangunan di segala bidang termasuk infrastruktur pendukung pembangunan perlu dilakukan, namun di sisi lain menghasilkan bongkahan sampah seperti material bangunan. Selain itu juga terlihat adanya pembangunan perumahan penduduk yang juga menghasilkan sampah material bangunan seperti keramik. Jenis sampah lainnya yaitu logam yang berasal dari aktivitas masyarakat. Secara keseluruhan sampah meso lebih banyak ditemukan pada kedalaman tertentu, artinya bahwa sampah tersebut telah tertimbun dalam kurun waktu yang lama. 
Tabel 1. Klasifikasi jenis sampah meso di perairan Desa Rumah Tiga

\begin{tabular}{|c|c|c|c|c|}
\hline No & Jenis & Kode & Klasifikasi sampah & Gambar \\
\hline 1 & $\begin{array}{l}\text { Kaca dan } \\
\text { keramik }\end{array}$ & GC07 & Pecahan kaca dan keramik & \\
\hline 2 & $\begin{array}{l}\text { Kaca dan } \\
\text { keramik }\end{array}$ & GC01 & $\begin{array}{l}\text { Material bangunan } \\
\text { (Bata, semen, pipa) }\end{array}$ & \\
\hline 3 & Plastik & PL 01 & Tutup botol & \\
\hline 4 & Plastik & PL 04 & $\begin{array}{l}\text { Pisau, garpu, sendok, sedotan, } \\
\text { pengaduk dan peralatan masak }\end{array}$ & \\
\hline 5 & Logam & ME08 & Serpihan logam & \\
\hline 6 & Logam & ME10 & $\begin{array}{l}\text { Kategori logam lainnya termasuk di } \\
\text { dalamnya peralatan bekas }\end{array}$ & \\
\hline
\end{tabular}

Persentase berat sampah meso tertinggi ditemukan pada jenis sampah kaca dan keramik (GC01) dengan klasifikasi material bangunan berupa bongkahan semen yaitu sebesar $60.53 \%$ (Gambar 4). Walaupun jumlah jenis sampah ini terbesar kedua setelah pecahan kaca dan keramik namun beratnya lebih besar. Pembangunan jembatan mengahasilkan limbah yang berasal dari penghancuran berupa bongkahan semen. Limbah ini akan memberikan dampak bagi keberadaan organisme seperti kerang-kerangan. Jenis kerang-kerangan bivalvia dapat hidup pada wilayah berpasir hingga berumpur (Akhrianti, $d k k ., 2014)$, namun tidak dengan habitat berupa bongkahan semen. Sebaliknya, limbah bongkahan semen dapat menberikan manfaat apabila dimanfaatkan sebagai media rehabilitasi terumbu karang (Setiawan, $d k k ., 2018$ ).

Kepadatan sampah meso tertinggi terdapat pada sampah jenis pecahan kaca dan keramik yaitu sebesar 1.55 item $/ \mathrm{m}^{2}$ (Gambar 5). Dalam proses produksi kaca dan keramik mengandung logam berat, seperti diketahui bahwa logam 
berat yang mencemari lingkungan perairan dapat membahayakan organisme perairan. Logam berat kadmium (Cd) asetat banyak digunakan pada proses industri porselen dan keramik (Rompas, 2010). Selanjutnya dikatakan bahwa, keberadaan kadmium di lingkungan berhubungan erat dengan keberadaan logam $\mathrm{Pb}$ dan Zn. Hingga saat ini diketahui bahwa kadmium merupakan logam berat paling banyak menimbulkan keracunan dan sebagai pencetus karsinogen pada makhluk hidup. Beberapa hasil penelitian menunjukkan bahwa logam kadmium yang terkonsetrasi di perairan akan dapat meningkat pada tubuh organisme ikan (Martuti, $d k k$., 2016; Hananingtyas, 2017)). Selain kadmium, logam berat lainnya yang digunakan sebagai bahan campuran dalam industri kaca dan keramik yaitu kobalt. Kobalt bersifat tidak larut dalam air, sehingga apabila diserap oleh organisme perairan akan berlanjut ke organsime tingkatan berikutnya melalui proses rantai makanan.

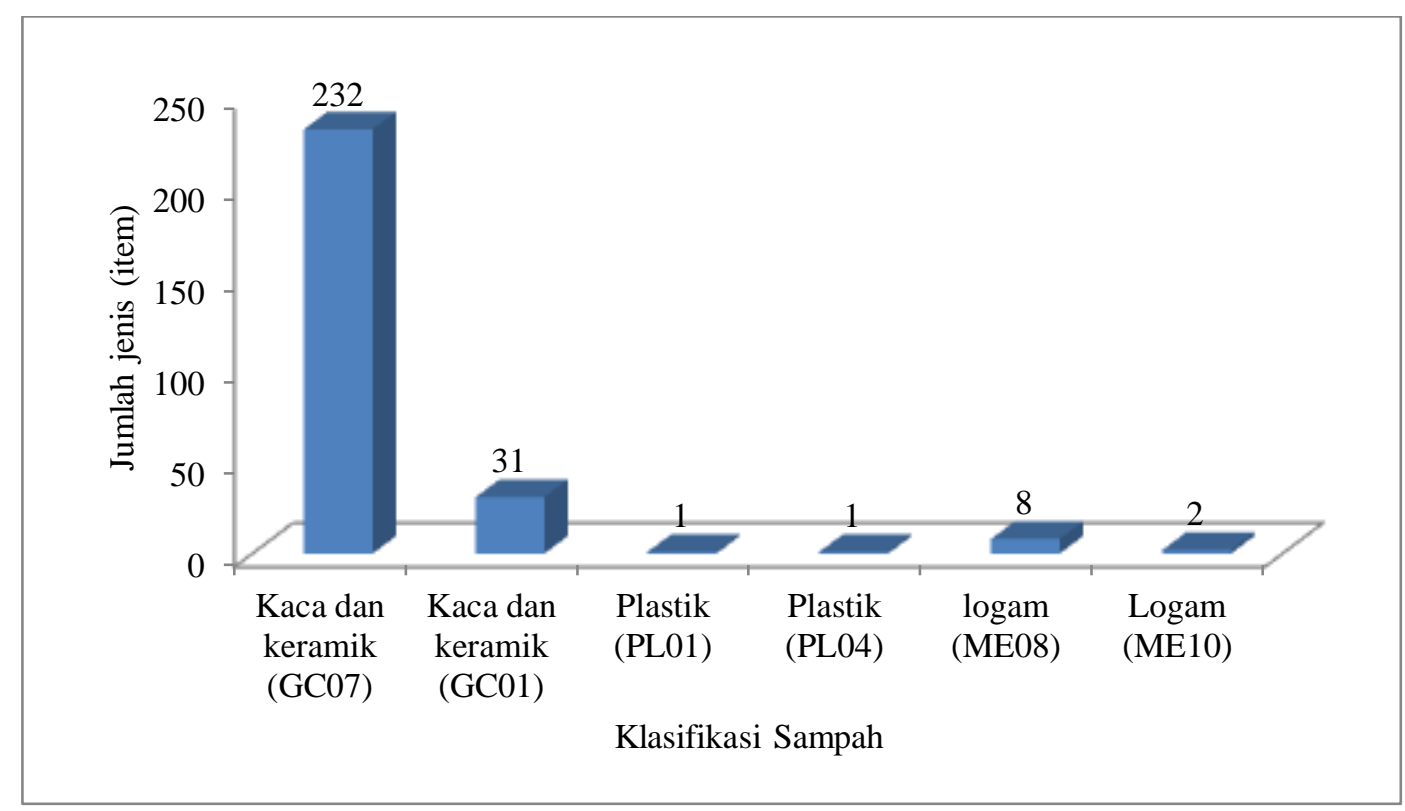

Gambar 3. Jumlah jenis sampah messo di pesisir Desa Rumah Tiga

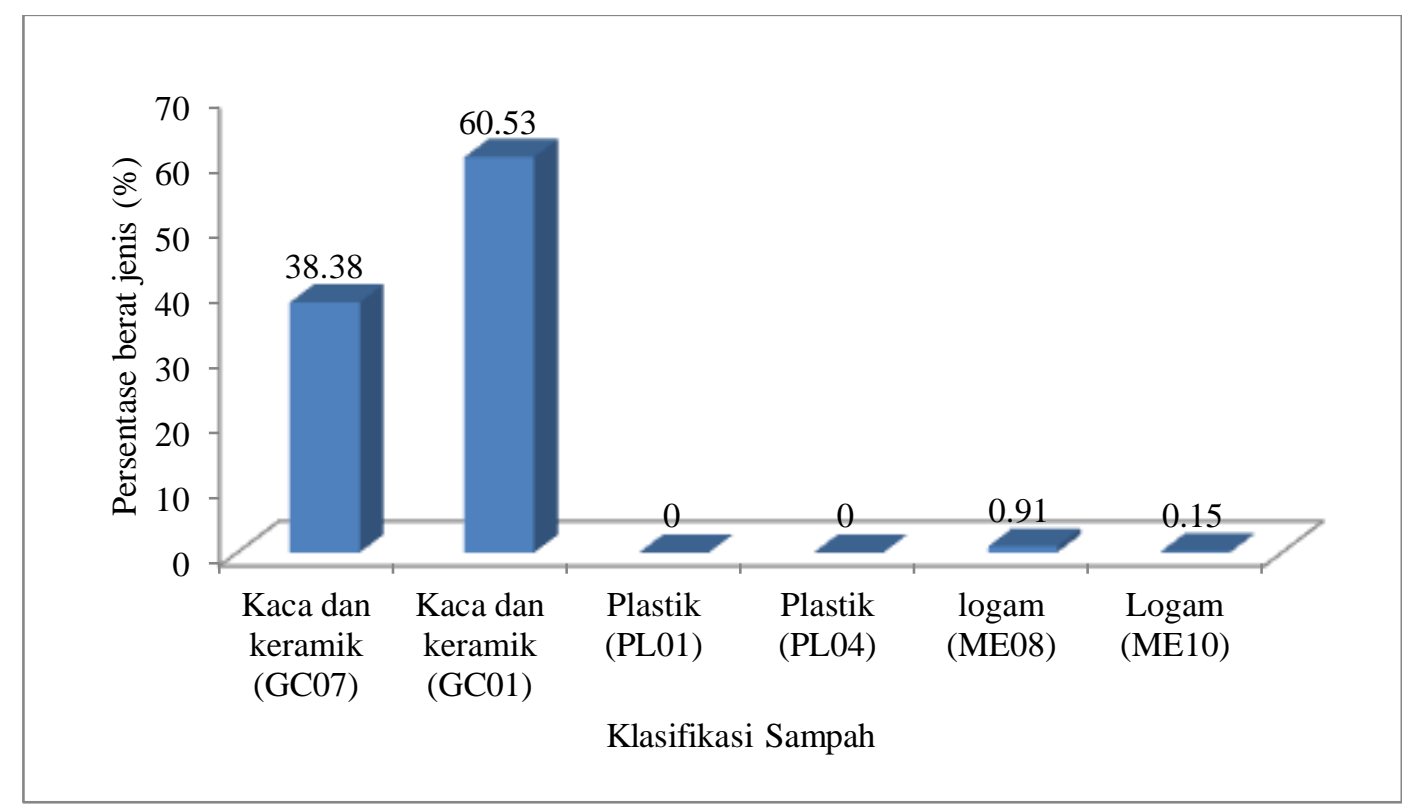

Gambar 4. Persentase berat jenis sampah meso di pesisir Desa Rumah Tiga 


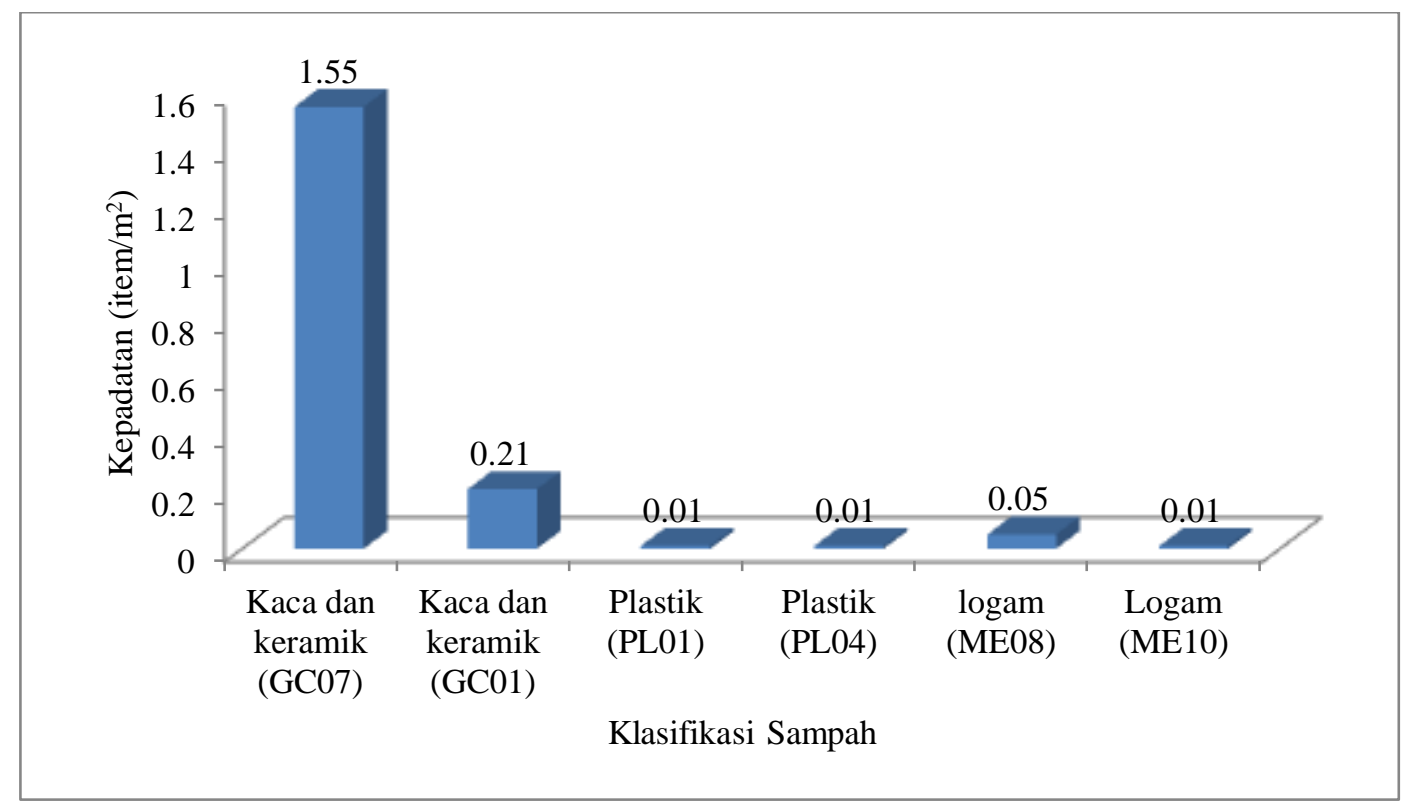

Gambar 5. Kepadatan jenis sampah meso di pesisir Desa Rumah Tiga

Sampah makro yang ditemukan di pesisir Desa Rumah Tiga sebanyak tujuh klasifikasi sampah yang tergolong dalam tiga jenis sampah yaitu kaca dan keramik, plastik serta logam (Tabel 2). Seperti halnya sampah meso, klassifikasi sampah pecahan kaca dan keramik memiliki jumlah jenis terbanyak yaitu 131 item, selanjutnya diikuti oleh material bangunan berupa bongkahan semen dan bata yaitu sebanyak 86 item (Gambar 6). Persentase berat jenis sampah makro tertinggi ditemukan pada klasifikasi sampah material bangunan yaitu sebesar $74.78 \%$ (Gambar 7). Pada sampah makro ditemukan sampah plastik berupa sedotan dan senar monofilament yang lebih banyak jumlahnya dibandingkan dengan sampah meso.

Sampah senar monofilament berasal dari aktivitas memancang masyarakat. Pantai Desa Rumah Tiga juga sering digunakan untuk memancing dan bukan hanya oleh masyarakat Desa Rumah Tiga saja, namun juga oleh masyarakat sekitar. Limbah sedotan saat ini merupakan limbah plastik yang banyak di perairan. Sebanyak 93 juta batang sedotan plastik digunakan dalam sehari di seluruh
Indonesia (https://www.merdeka.com/peristiwa /dalam-satu-hari-ada-93-juta-sampah-sedotanplastik-di-indonesia.html). Sedotan plastik memiiki kandungan polypropylene dan polystyrene. Keduanya merupakan komoditas polimer yang membentuk plastik dan banyak ditemukan di pesisir dan laut. Seperti diketahui sampah plastik merupakan sampah yang sulit terurai, namun saat ini telah banyak ditemukan partikel mikroplastik pada tubuh biota laut. Mikroplastik merupakan fragmen dari plastik yang terdegradasi dengan ukuran partikel kurang dari $5 \mathrm{~mm}$. Kecilnya ukuran partikel tersebut sehingga mikroplastik dapat termakan dan terakumulasi dalam biota pesisir dan laut (Li, et al., 2016). Penelitian telah membukttikan bahwa keberadaan partikel mikroplastik telah teridentifikasi pada air laut, beberapa biota perairan antara lain ikan dan kerang-kerangan (Zhao, et al., 2014; Rochman, et al., 2015; Zhang, et al., 2017). Partikel mikroplastik yang masuk ke tubuh biota dapat merusak saluran pencernaan/penyumbatan usus dan berpotensi terjadi keracunan bahan kimia yang dikandung dalam mikroplastik, sehingga menyebabkan kematian. 
Tabel 2. Klasifikasi jenis sampah makro di perairan Desa Rumah Tiga

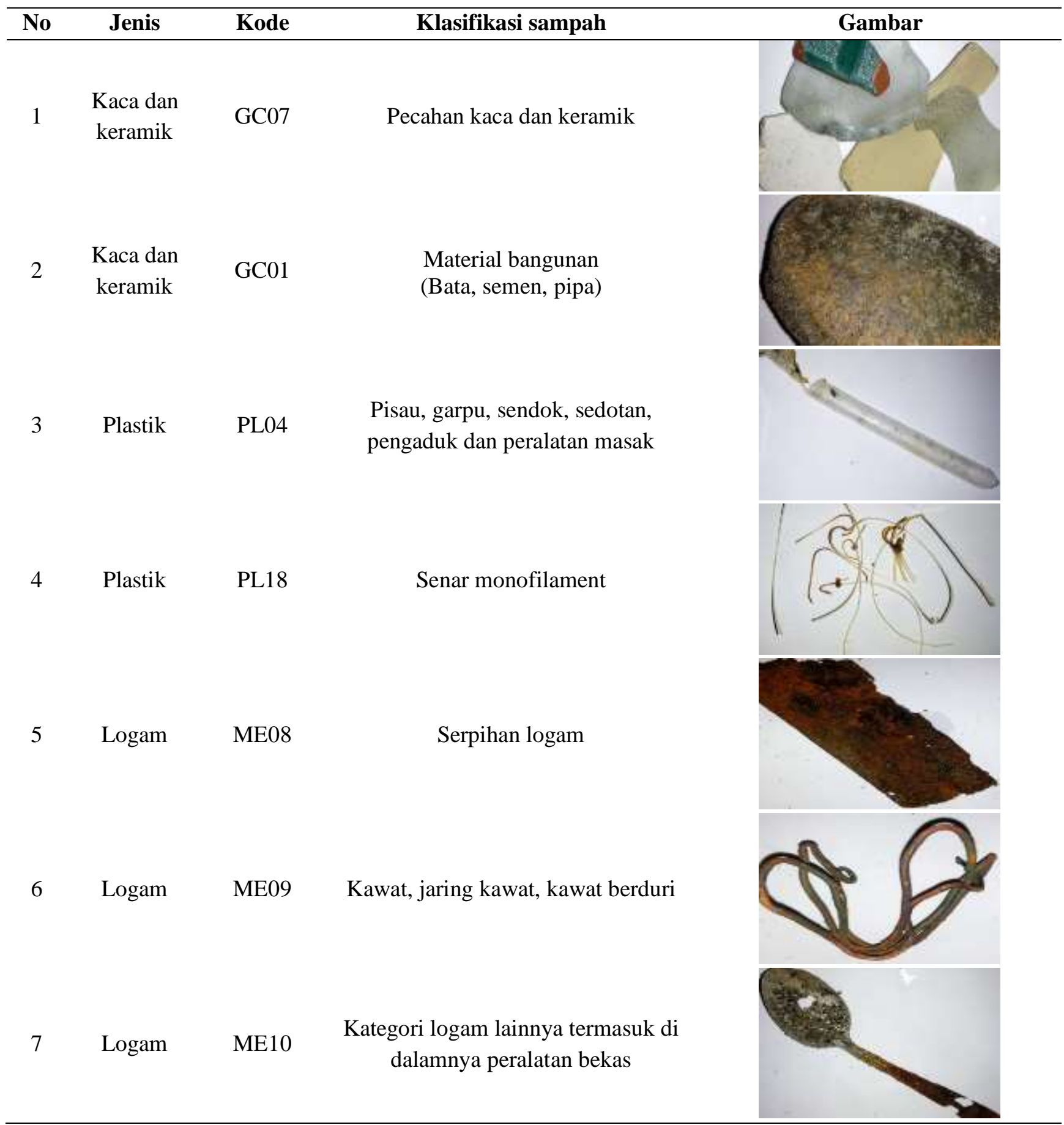




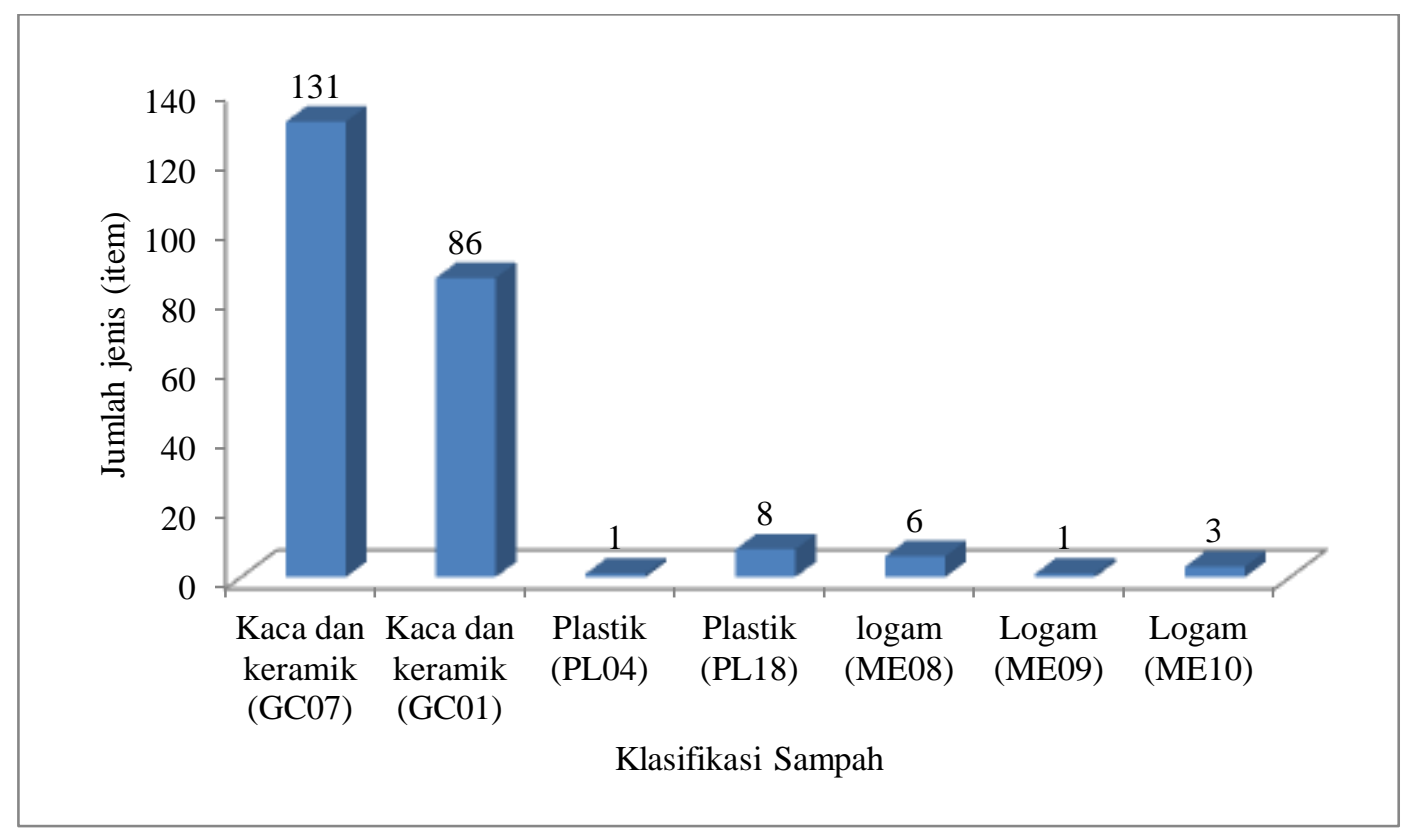

Gambar 6. Jumlah jenis sampah makro di pesisir Desa Rumah Tiga

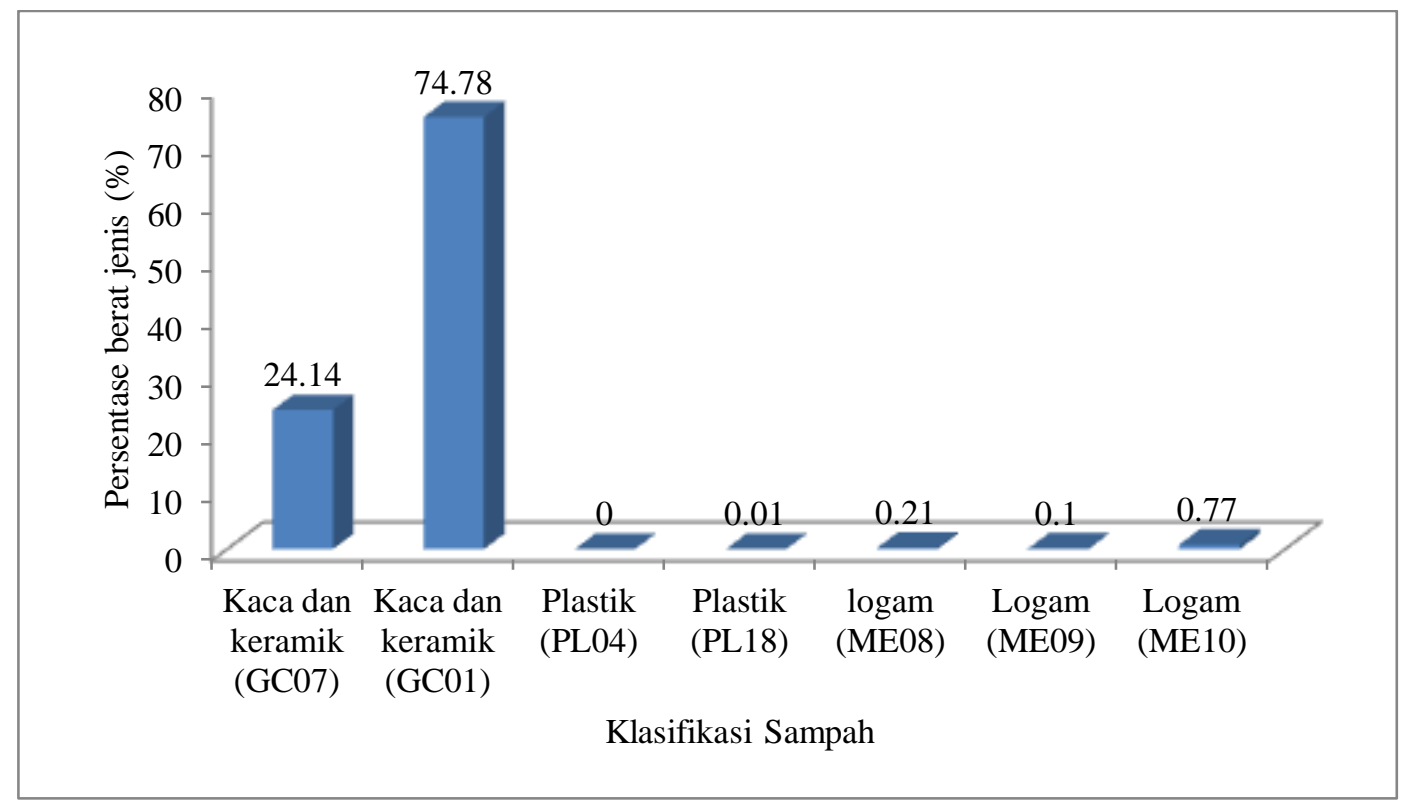

Gambar 7. Persentase berat jenis sampah makro di pesisir Desa Rumah Tiga

Kepadatan sampah makro tertinggi ditemukan pada klasifikasi sampah pecahan kaca dan keramik yaitu sebesar 0.87 item $/ \mathrm{m}^{2}$ (Gambar 8). Pada sampah meso dan sampah makro ditemukan jenis sampah logam dengan klasifikasi kawat, uang koin (logam) dan peralatan bekas rumah tangga. Seperti diketahui, uang logam terbuat dari bahan dasar alumunium, nikel dan kuningan. Buangan limbah yang mengandung nikel (Ni) mengakibatkan polutan di tanah, peraiaran dan tanaman (Rompas, 2010). Selanjutnya dikatakan bahwa nikel yang masuk ke sekosistem perairan laut dapat berasosiasi dengan biota laut terutama bagi rumput laut dan padang lamun, sehingga melalui rantai makanan akan bermuara pada manusia sebagai konsumen terakhir. Kuningan merupakan paduan logam tembaga $(\mathrm{Cu})$ dan seng ( $\mathrm{Zn})$. Kedua logam berat ini termasuk dalam logam berat esensial yaitu logam dalam 
jumlah tertentu yang sangat dibutuhkan oleh organsime. Namun demikian, konsentrasi kedua logam berat ini tidak boleh berlebihan jika terdapat pada tubuh ikan maupun kerangkerangan. Beberapa penelitian telah menunjukkan adanya kandungan logam berat $\mathrm{Cu}$ dan $\mathrm{Zn}$ pada tubuh ikan karena perairan yang juga telah tercemar (Suyanto, dkk., 2010; Rajkowska and Protasowicki, 2013). Hasil penelitian juga menunjukkan logam berat pada sedimen dasar memiliki konsentrasi lebih tinggi dibandingkan dengan kolom air karena terjadi pengendapan atau penimbunan bahan tersuspensi secara terus menerus (Siregar dan Edward, 2010). Pencemaran logam berat pada ikan juga akan menurunkan nilai jual atau ekspor ikan secara internasional. Hal ini akan menurunkan pendapatan Indonesia sebagai negara yang memiliki potensi sumberdaya perikanan tersbesar.

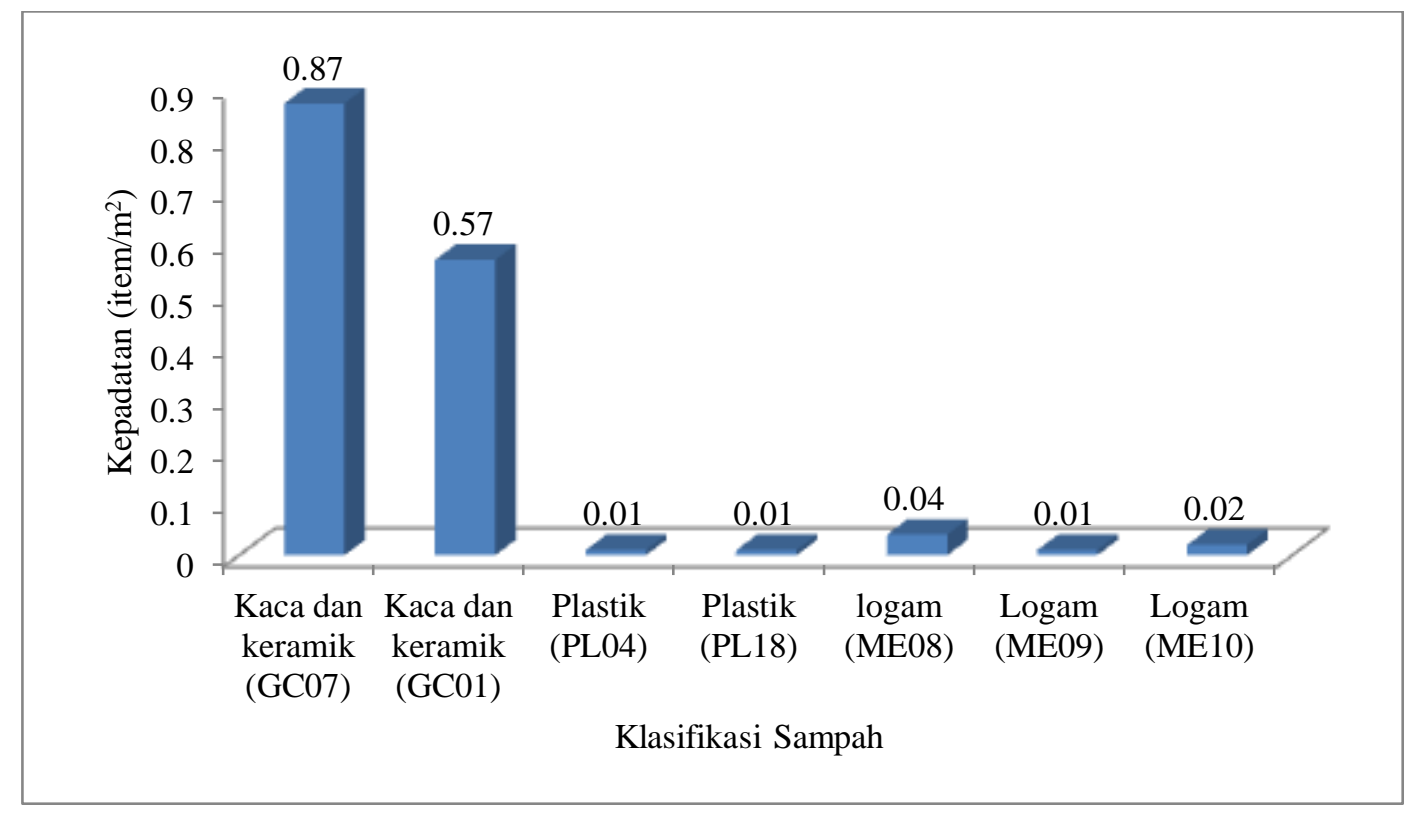

Gambar 8. Kepadatan jenis sampah makro di pesisir Desa Rumah Tiga

\section{KESIMPULAN DAN SARAN}

Berdasarkan uraian dan pembahasan yang telah dijelaskan, maka dapat diambil kesimpulan bahwa pada sampah meso dan makro, klasifikasi sampah pecahan kaca dan kemarik memiliki jumah jenis dan kepadatan tertinggi. Persentase berat untuk klasifikasi sampah material bangunan berupa bongkahan semen memiliki nilai tertinggi.

\section{DAFTAR PUSTAKA}

Akhrianti, I., D. G. Bengen, I. Setyobudiandi. 2014. Distribusi Spasial dan Preferensi Habitat Bivalvia di Pesisir Perairan Kecamatan Simpang Pesak Kabupaten Belitung Timur.
Jurnal Ilmu dan Teknologi Kelautan Tropis 6(1): 171-185.

Badan Pusat Statistik. 2018. Kota Ambon dalam Angka 2018. Badan Pusat Statistik Kota Ambon.

Cole, M., P. Lindeque, C. Halsband, T.S. Galloway. 2011. Microplastics as Contaminants in The Marine Environment: A Review. Mar. Pollut. Bull., 62: 25882597, 10.1016/j.marpolbul.2011.09.025.

Hananingtyas, I. 2017. Studi Pencemaran Kandungan Logam Berat Timbal $(\mathrm{Pb})$ dan Kadmium (Cd) pada Ikan tongkol (Euthynnus sp.) di Pantai Utara Jawa. Biotropic The Journal of Tropical Biology 1(2): 41-50.

https://www.merdeka.com/peristiwa /dalam-satuhari-ada-93-juta-sampah-sedotan-plastik-diindonesia.html. (Online). Diakses tanggal 12 Maret 2019. 
Li J., X. Qu., L. Su., W. Zhang, D. Yang, P. Kolandhasamy, D. Li, and H. Shi. 2016. Microplastics in Mussels Along The Coastal Waters of China. Environmental Pollution 214: 177 - 184.

Martuti, N.K.T., H. A. Sanjivanie, S. Ngabekti. 2016. Bioakumulasi Kadmium Pada Ikan Bandeng di Tambak Dukuh Tapak Semarang. Jurnal MIPA 39 (2): 92-97.

Plastic Europe. 2016. Plastic-The Facts 2016: An Analysis of European Plastics Production, Demand and Waste Data. http://www.plasticseurope.org.

Poeta, G., E. Staffieri, A. T. R. Acosta, C. Battisti. 2017. Ecological Effects of Anthropogenic Litter on Marine Mammals: A Global Review With a "Black-List" of Impacted Taxa. Hystrix, The Italian Journal of Mammalogy 28(2): 253-264.

Rajkowska, M., M. Protasowicki. 2013. Distribution of Metals ( $\mathrm{Fe}, \mathrm{Mn}, \mathrm{Zn}, \mathrm{Cu}$ ) in Fish Tissues in Two Lakes of Different Trophy in Northwestern Poland. Environ. Monit. Assess 185: 3493-3502.

Rarastri, A. D. 2008. Kontribusi Sampah Terhadap Pemanasan Global. Kementerian Negara Lingkungan Hidup.

Rochman, C. M., Tahir,A.,Baxa, D.V.,Williamsm S., Werorilangi, S. And Teh, S.J. 2015. Anthropogenic Debris in Seafood: Plastic Debris and Fibers From Textiles in Fish and Bivalves Sold for Human Consumption. Sci. Rep. 5, 14340; doi: 10.1038/ srep14340.
Rompas, R. M. 2010. Toksikologi Kelautan. Penerbit Sekretariat Dewan Kelautan Indonesia. PT. Walau Bengkulen. 338p.

Setiawan, S., L. Anshari, O. Lolopayung, Subhan, Risfandi. 2018. Pemanfaatan Limbah Hasil Konstruksi Bangunan Sebagai Bahan Utama dalam Rehabilitasi Terumbu Karang. Jurnal Manajemen Sumberdaya Perairan 3(3): 255261.

Siregar, Y. I., J. Edward. 2010. Faktor Konsentrasi $\mathrm{Pb}, \mathrm{Cd}, \mathrm{Cu}, \mathrm{Ni}, \mathrm{Zn}$ Dalam Sedimen Perairan Pesisir Kota Dumai. Maspari Journal 1: 1-10.

Suyanto, A., S. Kusmiyati, Ch. Retnaningsih. 10. Residu Logam Berat Ikan dari Perairan Tercemar di Pantai Utara Jawa Tengah. Jurnal Pangan dan Gizi 1(2): 33-38.

Waluyo, H., Sakdulla, A. Prajati, D. Arifin, R. L. Simamora \& S. Bayuaji. 2017. Pedoman Pemantauan Sampah Pantai. Dirjen Pengendalian Pencemaran dan Kerusakan Lingkungan. Kementerian Lingkungan Hidup dan Kehutanan. Jakarta. 52 p.

Zhang W, Zhang S, Wang J, Wang Y, Mu J, Wang P, Lin X, Ma D. 2017. Microplastic Pollution in The Surface Waters of The Bohai Sea, China. Environ Pollut 231 (1): 541-548.

Zhao, S., L. Zhu, T. Wang, D. Li. 2014. Suspended Microplastic in The Surface Water of The Yangtze Estuary System, China: First Observations on Occurrence, Distribution. Marine Pollution Bulletin 86: 562-568. 